\begin{tabular}{ll}
\hline \hline Finans Ekonomi ve Sosyal Araştırmalar Dergisi Cilt5/Sayl4 & Makale Geliş Tarihi: 21.11 .2020 \\
Research of Financial Economic and Social Studies (RFES) & Makale Yayın Tarihi: 31.12 .2020 \\
ISSN : $2602-2486$ & DOI: $:$ 10.29106/fesa.829187 \\
\hline \hline
\end{tabular}

\title{
STRATEGIC MANAGEMENT AND STRATEGIC LEADERSHIP IN PUBLIC ORGANIZATIONS
}

\section{KAMU KURULUŞLARINDA STRATEJIKK YÖNETIM VE STRATEJIK LIDERLIK}

Harika Suklun ${ }^{1}$

\begin{abstract}
For decades strategic management and strategic leadership focused on the private sector only. Managing public organizations received critics from many, and there is a common belief that public organizations' management is poor. Recent changes are affecting the private sector and public organizations as well. Due to the growing complexity of social problems and increasing demands of citizens to administration, strategic management has become a needed tool for the public manager to create value and to shape the organization. On the other hand, the acceleration of social change creates more challenges for public administration. Public and private organizations exist for different reasons, so applying the same strategies to each organization would not be wise. The purpose of public organizations is to serve its citizens, and the existence of private organizations is profit-making. Therefore this paper aims to explore if public organizations are advanced in the implication of strategic management and strategic leadership.
\end{abstract}

Keywords: Strategic Management, Strategic Leadership, Public Organizations

JEL Codes: M0, M1, M19

ÖZ

Onlarca yıldır stratejik yönetim ve stratejik liderlik sadece özel sektöre odaklanmıştır. Kamu kuruluşlarını yönetimi çok fazla eleştiriler almakta ve hatta kamu kuruluşlarının yönetiminin zayıf olduğuna dair yaygın bir inanç bulunmaktadır. Son dönemdeki değişiklikler özel sektörü etkilediği kadar kamu kuruluşlarını da etkilemektedir. Toplumsal sorunların artan karmaşıklığ ve vatandaşların yönetime artan talepleri nedeniyle, stratejik yönetim, kamu yöneticisinin değer yaratması ve örgütü şekillendirmesi için gerekli bir araç haline gelmiştir. Öte yandan, sosyal değişimin hızlanması da kamu yönetimi için daha fazla zorluk yaratmaktadır. Kamu ve özel kuruluşlar farklı nedenlerle oluşmuştur ve bu nedenle her kuruluşa aynı stratejileri uygulamak uygun olmamaktadır. Kamu kuruluşlarının amacı vatandaşlarına hizmet etmek ve özel kuruluşların amacı ise kar sağlamaktır. Bu nedenle bu makale, kamu kuruluşlarının stratejik yönetim ve stratejik liderliğin uygulanmasında ileri düzeyde olup olmadığını araştırmayı amaçlamaktadır.

Anahtar Kelimeler: Stratejik Yönetim, Stratejik Liderlik, Kamu Kuruluşları

JEL Kodu: M0, M1, M19

${ }^{1}$ Dr. Öğretim Üyesi, Abdullah Gül Üniversitesi, Harika.suklun@agu.edu.tr, ORCID: 0000-0003-1016-268X 


\section{INTRODUCTION}

Interest in strategic management is growing and becoming crucial in several public organizations, and enhancing progressively relevant in practice due to changes (Höglund et al., 2018; 832). Strategic Public Management is about mingling hierarchy with the collaboration that is not applied only in a planning unit but consists of the organization-wide. The implementation of a strategy is an integral part of the strategy process (Marin, 2016; 188). Furthermore, it is looking forward to options of how to develop supplementary strategies into an instrument that better assists strategic management in the public sector (Steurer, 2007; 209).

Strategic management has become a standard tool for the public manager to create value and to shape the organization. The growing complexity of social problems and the increasing demands of citizens towards public organizations are a couple of reasons why strategic management and leadership should be applied in public organizations. While talking about public organizations, politicians cannot be left out because of their involvement in public administration. In governments, when the political party changes, the administration changes in the same direction, which makes management issues more complex. As discussed in many studies the speed of social change, public administration has become a more partner of politicians (Kooiman \& van Vliet 2020; 361, Joyce, 2000; 108, Williams \& Lewis, 2008; 655), especially in the area of building values and the way of building those values. Although there are similarities in both public organizations and private organizations, they exist for different reasons. Nutt and Backoff $(1993 ; 315)$ differentiate public organizations and private organizations based on environmental and transactional factors and internal processes.

The environmental factors include the influence of the political level and constraints put on public organizations by legal mandates and "market forces" of key actors and funders which expect public organizations to collaborate to achieve social aims.

The transactional factors include coerciveness, the scope of impact which is much broader than in a private company, public scrutiny of all transactions, and thus the need for accountability and ownership which is collective, and thus management must include societal values such as fairness, openness, inclusiveness, honesty.

In the past, most of the debates on the implication of strategic management and leadership are focused on the private sector (Lane and Wallis, 2009; 115, Kerlinová and Tomášková, 2014; 89, Höglund and Svärdsten, $2015 ; 832$ ). Thus, it might be one of the reasons why the public sector still faces challenges in implementing strategic management and leadership. Managing public organizations received critics from many, and there is a common belief that public organizations' management is poor. For example, Lane and Wallis (2009; 101) call public management an "organized foolishness in the public organization". Currently, with the economic downturn, budgets have been cut, resources to do the job have decreased, and several employees have been laid off. These conditions have made public employees and managers feel insecure about their future and they lost motivation. The situation might be one of the reasons for poor management.

In the last several decades, the economy, internal and external environment of organizations, the competition, the demography of people, technologies, and among others have changed tremendously (Hansen and Ferlie, 2016; 9). These changes are affecting both private organizations and public organizations as well. For example, because of globalization, public organizations are forced to enter the international competition arena. In addition to globalization, demographic, societal changes, and the shifting values of a diverse population are challenging public administrators to respond to the diverse needs of the citizens they serve (OEDC, 2015; 2). Other changes that might be affecting management in a public organization are ethics and social responsibility, speed of responsiveness, and the digital workplace.

Because of recent changes, it is expected that the governmental structure, the public work, the type of employment, and the competition for general tax revenues would change soon. According to Goulet (1996; 12), some of these changes will need strong political and public service leadership. Public organization's leaders are already looking for solutions to these new, upcoming strategic changes. Joyce $(2004 ; 108)$ theorized that budgetary systems must be responsive to strategic changes to gain benefits from strategic planning and management in the public sector. McBain and Smith $(2010 ; 5)$ analyze strategic management application for public sector organizations and specific challenges when the public organizations decide to apply strategic management. In sum, to overcome the current financial, social, and political challenges, public sector organizations need to rethink, adapt, and thus reengineer their underlying service processes (Jurisch et al., 2015; 17).

According to the Organization for Economic Co-operation and Development (OEDC) report $(2015 ; 10)$, leadership development is not new and exclusive to the public sector, but strategic leadership is missing in public organizations. Although for a long time strategic leadership has become a critical subject in the public sector the application is still not common. Lane and Wallis $(2009 ; 110)$ also noted that the connection between leadership and public sector productivity has been ignored by many disciplines especially in economics. 


\section{Literature Review}

Applying the same methods and tools used for management in private organizations to public organizations has been discussed among scholars and professionals. Agreeing with Önder (2018) one of the tactics is the application of the principles and tools of strategic management in public organizations. Strategic management is described as formulating, implementing, and evaluating decisions that would lead organizations to accomplish their objectives. According to Gecíková and Papcunová (2014), implementing strategic management and strategic leadership in public organizations is not easy.

Strategic management activities are embattled at preserving long-term uniformity between the mission, identified objectives, available sources, and the relationship with environment and organization (as cited in Ochrana, 2010). Because of those activities, the implications of strategic management and leadership in public organizations become harder. Shrivastava and Nachman (1989) identified four different strategic leadership patterns as follows.

1. The entrepreneurial pattern; consists of four variables which include the followings:

a. leadership makes roles, roles for others and controls their performance through direct supervision

b. personal traits,

c. personality and charisma; and

d. direct control.

2. The bureaucratic pattern consists of five variables:

a. members take on roles;

b. bounded by rules;

c. official rules and organizational structure;

d. closed system; and

e. $\quad$ rules are interpreted.

They indicated the strategic direction and drive of the company is not guided by a person, or even a group instead, the bureaucracy and its associated system typical operating procedures and policies form the strategy.

3. The political pattern consists of four variables:

a. reciprocal interdependence,

b. dominant coalition,

c. impersonal roles and

d. organizational or subsystem level.

The political pattern represents organizations where either an entrepreneurial or a bureaucratic direction directs strategy building.

4. The professional pattern consists of four variables:

a. control over information;

b. open systems;

c. small group dyad or individual level; and

d. creates new rules.

Nutt and Backoff (1993) reviewed and contrasted four leadership approaches and recognized the development of each approach while including the source of vision (strategy). Furthermore, they suggested a direction process with its supporting steps. Each method is named related to attempts that "describe the successful leader; use language creatively; interpret what successful leaders do, and derive leadership principles from exemplary followership." Although strategic planning and management in public organizations are widely known, there is still a need for work on this subject. Bryson and George (2020) suggest that scholars should feel fortified to engage with this timely issue. Moreover, scholars should also investigate what works best, in which situation and why, (Bryson and George, 2020), which would help to progress in the application of strategic management in public organizations.

\section{A. Differences Between Public Organizations and Private Organizations}

There are dissimilarities between the two sectors; the main difference is the purpose of existence. The existence of the public organization is to serve citizens, on the other hand, the profit-making is the existence of the private organization. In terms of ownership, private organizations are owned, managed, and controlled by individuals where public organizations are owned and managed by governments. Although with the privatization (Pfiffner, 2004) more and sectors are found in both sectors, for example, education, healthcare, etc. still some sectors are kept in the public sector such as telecommunication, electricity, army, safety, postal service, border control, etc. Below table 1 exhibits the general differences. 
Table 1. Differences Between Public and Private Sector

\begin{tabular}{|c|c|c|}
\hline & PUBLIC SECTOR & PRIVATE SECTOR \\
\hline Meaning & $\begin{array}{l}\text { The section of a nation's economy, } \\
\text { which is under the control of the } \\
\text { government, whether it is central, } \\
\text { state, or local. }\end{array}$ & $\begin{array}{l}\text { The section of a nation's economy, } \\
\text { which owned and controlled by private } \\
\text { individuals or companies. }\end{array}$ \\
\hline Basic objective & To serve the citizens of the country. & Earning Profit \\
\hline Budget & $\begin{array}{l}\text { Public Revenue like tax, duty, } \\
\text { penalty, etc. }\end{array}$ & $\begin{array}{l}\text { Issuing shares and debentures or by } \\
\text { taking a loan }\end{array}$ \\
\hline Example Areas & $\begin{array}{l}\text { Police, Army, Mining, Health, } \\
\text { Electricity, Education, Transport, } \\
\text { Telecommunication, Agriculture, } \\
\text { Banking, Insurance, etc. }\end{array}$ & $\begin{array}{l}\text { Finance, Information Technology, } \\
\text { Mining, Transport, Education, } \\
\text { Telecommunication, Manufacturing, } \\
\text { Banking, Construction, } \\
\text { Pharmaceuticals, etc. }\end{array}$ \\
\hline Employment & $\begin{array}{l}\text { Job security, Retirement benefits, } \\
\text { Allowances, Perquisites, etc. }\end{array}$ & $\begin{array}{l}\text { Good salary package, Competitive } \\
\text { environment, Incentives, etc. }\end{array}$ \\
\hline Promotion & Seniority & Merit \\
\hline Job Stability & Yes & No \\
\hline
\end{tabular}

Source: https://keydifferences.com/difference-between-public-sector-and-private-sector.html

According to Chen (2006), governments are bureaucratic organizations they fall into Machine organization on Mintzberg's six basics organization structural configurations include "strategic apex; middle management; operating core; technical support staff; and administrative support staff" (as cited in Mintzberg, 1998, p.132). Although governments have many administrative employees, the technical support staff is the leading team in machine organizations and, critical decisions are made at the top. As reported by Chen (2006) in machine organizations such as governments and public organizations, the hierarchy should be re-formalized.

Although private organizations follow legislations, etc., public organizations place precise demands on the management, such as reporting to several authorities, dealing with the influence of legislation, and the political force (Smini and Nistelrooij, 2006). Those demands are one of the main differentiations between private and public organizations. The other main difference between the two organizations is their markets, and public organization is limited in production (Kerlinová and Tomášková, 2014). Public organizations' market is established by rules that form boards, public officials (Nutt and Backoff, 1993). Furthermore, usually, it is hard to specify goals and equity concerns as imperative as effectiveness in public organizations (Nutt and Backoff, 1993). Moreover, public organizations exist to serve their citizens and fulfill the demands (Taner, 2018). Agreeing with Hassan (2009), public organizations must provide services to the citizens from birth to the grave and not left out the needs of diverse citizens as well.

Another difference between private and public organizations is goal setting. According to Nutt and Backoff (1993), private organizations can set goals of profit; in contrast, in public organizations setting a goal of profit is not applicable. Just the opposite of that usually, public organization's goals are unclear and contradict. Additionally, they discussed that "the difficulty of setting goals can supersede the development of strategic options" (Nutt and Backoff, 1993; 313). Thus, strategic leaders should elude applying private-sector methods to strategic management in public organizations.

\section{B. Strategic Leadership}

There are several different types of leadership that each leadership style has advantages and disadvantages. The effectiveness of organizational leaders depends on the organizational culture, employee personalities and experience levels, etc. Thus, a specific type of leader may not fit in an organization but may comply in another organization. The personality of leaders affects motivating employees thus leaders should 
understand their own organizational culture too. Below table 2 exhibits the basic approaches to organizational leadership.

\begin{tabular}{|c|c|c|c|}
\hline \multicolumn{4}{|c|}{ Table 2. Basic Approaches to Organizational Leadership } \\
\hline Leadership Type & Descriptors & Strengths & Weakness \\
\hline $\begin{array}{l}\text { I: Visionary } \\
\text { (principles) }\end{array}$ & $\begin{array}{l}\text { Deep thrust } \\
\text { Architectonic } \\
\text { Intuitive } \\
\text { Metaphysical } \\
\text { Visionary }\end{array}$ & $\begin{array}{l}\text { Principles, insight } \\
\text { understanding, } \\
\text { wisdom, sagacity, } \\
\text { generate core ideas/values }\end{array}$ & $\begin{array}{l}\text { Idealistic, impersonal } \\
\text { remote, abstract } \\
\text { impractical } \\
\text { (under-emphasis or lack } \\
\text { of type of III leadership qualities) }\end{array}$ \\
\hline II: Systems leader & $\begin{array}{l}\text { Rationality, System, } \\
\text { Structure, Stability, } \\
\text { Order, Predictability } \\
\text { Measurement \& Control } \\
\text { Practical. Impersonal }\end{array}$ & $\begin{array}{l}\text { Performance, } \\
\text { organizational efficiency } \\
\text { technical, expertise, }\end{array}$ & $\begin{array}{l}\text { Bureaucracy, red-tape; } \\
\text { impersonal, transactional, } \\
\text { uninspiring, inflexible } \\
\text { (under-emphasis or lack } \\
\text { of type of IV leadership qualities) }\end{array}$ \\
\hline II: Relationships & $\begin{array}{l}\text { Cooperation, Consultation } \\
\text { Negotiation, Consensus, Trust } \\
\text { Support, Expressive }\end{array}$ & $\begin{array}{l}\text { Persuasion, personal-engaged, } \\
\text { humanistic, develop people } \\
\text { servant, diplomat }\end{array}$ & $\begin{array}{l}\text { Gamesman, manipulative, } \\
\text { exploitative, utilitarian, } \\
\text { Narcissistic leader } \\
\text { (under-emphasis or lack } \\
\text { of type of I leadership qualities) }\end{array}$ \\
\hline IV: Transformational & $\begin{array}{l}\text { Strong team/group leader } \\
\text { Communal-engaged } \\
\text { Values (humanism) }\end{array}$ & $\begin{array}{l}\text { Heroic personality, } \\
\text { transcendent, humanistic } \\
\text { transformational } \\
\text { inspirational/charismatic }\end{array}$ & $\begin{array}{l}\text { totalitarian, misguided } \\
\text { missionary, disorderly } \\
\text { (under-emphasis or lack } \\
\text { of type of II leadership qualities) }\end{array}$ \\
\hline
\end{tabular}

In terms of strategic leadership, there are several definitions in the literature. Adair (2005) coined the phrase "strategic leadership" in 1970. According to him "it is an expansion of the original, for in Greek 'strategy' is made up of two words: Stratos, a large body of people; and the -egy ending, which means leadership" (para. 11). His basic definition of "Strategy is the art of leading a large body of people" (para. 11). Moreover, Naidoo (2009) defined strategic leadership as "strategic leadership is the ability to influence others to voluntarily make day-today decisions that enhance the long-term viability of the organization" (p. 48, as cited in Rowe, 2001). Since strategic leaders have strong, optimistic expectations, they exploit and exchange tacit and explicit knowledge and they believe in strategic choice. Thus, strategic leaders synergistically combine the two types of leadership; managerial and transformational leadership, and need to understand both to utilize and skills (Naidoo, 2009). The below list includes the feature of a strategic leader as follows (Naidoo, 2009 as cited in Rowe, 2001);

- $\quad$ The synergistic combination of transformational and managerial leadership

- $\quad$ Emphasis on ethical behavior and value-based decisions

- $\quad$ Operational oversee (day-to-day) and strategic (long-term) responsibilities

- Formulate and implement strategies for immediate impact and preservation of long-term

- $\quad$ goals to enhance organizational performance and long-term viability

- Have strong, positive expectations of performance they expect from their superiors, peers,

- $\quad$ subordinates and themselves

- $\quad$ Use and interchange, tacit and explicit knowledge on individual and organizational levels

- Use linear and non-linear thinking patterns

- Believe in strategic choice; that is, their choices make a difference in their organizations and environment

Similar to Naidoo's definition, Joyce (2004) defined strategic leadership as a key element in effective strategic management. He also emphasized that leaders' focal point is a strategic track and construct a program for strategic change and retain the organization continuing toward its strategic vision. He indicated that leaders are interested in the proper design of strategic planning systems in public service. Leaders in public organizations evaluate strategic planning systems to improve their decision making when to make overall changes in the organization. Most importantly, strategic leaders are elaborate in cumulating the knowledge of their organizations. 
Wanasika (2009) compared the distinctions of strategic leadership in various sciences and specified that strategic leadership differs from traditional leadership in organizational behavior, psychology, and other social sciences. Characteristics such as risk-taking, futuristic view, action-taking, and capacity of absorption are necessary for strategic leaders. Moreover, those characteristics are critical for the effectiveness of strategic motivation. On the other hand, according to Wanasika (2009) power of the strategic leader is not noteworthy in terms of the followers' support.

\section{Strategic Leadership In Public Organizations}

Since public organizations and private organizations are different, leadership will be distinctive as well. As Schall (1997) pointed out in public organizations, managers are susceptible to fluctuating political situations. For example, by the law, the local governments hypothetically change every four years with an election. Right after newly elected officials start, they make fundamental changes in the organizations. Similarly, Schall (1997) discusses that public sector leaders frequently allow the shifts to limit their opportunities. Additionally, Lemay (2009) also argues that in public organizations, the leaders have limited control, unlike leaders in private organizations.

According to Goulet (1996), there is a lack of defining leadership in the public sector and often confused with motivation. They suggest that an early clear definition of leadership would have helped the public sector leaders to understand its concept and put it into effect. According to Nutt and Backoff(1993), the specific essentials of public organizations are the same problems for strategic leadership as well. To implement a vision, strategic leaders in public organizations have many challenges and difficulties. Challenges and difficulties come from the leader being exposed to politics, dealing with subordinates, and keeping a low profile that is expected by political leaders (Nutt and Backoff, 1993).

After analyzing what type of leadership is suitable for different types of organizational structure, Chen (2006) noted that since machine organization is bureaucratic, transactional leadership is a better fit. He pointed out that charismatic leadership is medium, transformational leadership, and servant leadership is weak, for machine organizations. Furthermore, Pfiffner (2004) points out that monitoring and controlling employees' behavior from the top is not a way of achieving quick reactions and better service delivery. As Joyce (2004) expresses, strategic leaders retain organizational progressing in the direction of the strategic vision. In public organizations, usually strategic leaders give decision-making power and authority to managers and employees. The differences between leaders in public organizations and private organizations must not be ignored. The differentiation between these two sectors' organizational structures must be considered as well.

As it is in the private sector, public organizations need strong managers too. As Burgon (2009) discusses, managers in public organizations face more challenges than managers in the private sector. The biggest challenge is public organizations deal with more complicated problems. He argues that dividing the problems into small pieces is not a way of solving complex problems; instead, he suggests that with a systematic method, the overall system must be considered to find solutions to complex problems. According to Taylor (2009), retention of skilled human resources is a challenge for the strategic leaders during the execution of change. Subsequently, because of changes in every area, leaders need to gain new skills and methods for effective leadership.

Taylor (2009) also argued that public service today has to contend with six major transformational trends as follows "(1) rapidly changing citizen consumer profiles, preferences and value propositions; (2) systems and technology-driven products, services and competencies; (3) increasing interconnectedness among governments and organizations; (4) the increased need for public sector consolidations and accountabilities; (5) a higher sense of competition in both overseas and domestic markets and (6)increasing regulatory, supervisory and government policy interventions." These trends involve a new method of management, business, and leadership advancement.

\section{CHALLENGES}

Strategic leadership cannot be performed without strategic management. First, public leaders have to see a need for change. They must then practice strategic management and train leaders to become strategic leaders. Finally, they must put strategic leaders into action. According to Nutt and Backoff $(1993 ; 320)$, the strategic leaders' goal is to transform the organization by involving all of the shareholders in the process. This type of goal requires a long-term commitment, and the entire organization and its environment must be considered when changes to be made. Thus, strategic leadership is providing a guidance process for public organizations in the case of transformation. Nutt and Backoff $(1993 ; 301)$ suggested a guidance process as it is presented in the following table 3 .

Table 3. The Elements of Strategic Management and Strategic Leadership for Public and Third Sector Organizations

Stages of Strategic Management Stages of Strategic Leadership


1. Understand the history

Trends and events

Directions

Ideals development

2. Explore the situation SWOTs

3. Uncover issues

Issue tensions

Issue agenda

4. Identify the strategy

Join SWOTs and ideals with

priority issue tensions to identify the strategy

5. Assess feasibility

Resources

Stakeholders

6. Fashion implementation plan
1. Co-create strategy

Delegate to SMGs

Stress innovation

Add stages 1, 2, 3, 4, \& 5 of

strategic management

2. Frame vision for public consumption

Enlarge the strategy space

Switch filters and context

3. Blur leader-follower distinctions

Give away information

Empower followers

4. Push the action forward

Position in the stream of action

Promote by networking

Create positive energy

Path clear for empowered followers

Add stages 2, 3, \& 4 in strategic leadership

Source: Nutt, and Backoff (1993, p. 337)

In agreement with others, Montanari and Bracker $(1986 ; 259)$ also argue that public organizations are poorly managed over the long term. Additionally, organizational goals should replicate purposes earlier than recognizing and choosing strategic decisions. Missing structure of goals and related environmental analyses may be reasons for frequent cries of bureaucratic mismanagement in the public organizations. Although there are several theories, there is still a need for comprehensive theory and research on public sector organizations. Even though public organizations are aware of strategic leadership, the mentioned obstacles such as; political winds; having diverse customers; legislature and boards; limited control; and so forth are limiting these types of organizations by not allowing them to implement strategies as quickly as private sectors.

\section{CONCLUSION}

Improvement in the public management system is getting more attention than before, not only on a national level but also on an international level as well. For example, Uğurluoğlu, Çelik, and Pisapia $(2010 ; 35)$ noted that "in 2003, the Turkish government passed The Public Finance Management and Control Law No: 5018 into law to address some of the complexities and to improve public management" in general. The main reason for it was the importance of strategic management as an implementation to improve public organizations to prepare their strategic plans by a requirement. According to Uğurluoğlu, Çelik, and Pisapia (2010; 45), strategic planning would increase the effectiveness of financial management, and also support, develop and reinforce the organizational culture and identity.

Agreeing with other studies Sminia and Nistelrooij (2006; 109) also accepted that there are several profound dissimilarities between public and private organizations. Dissimilarities play critical roles when an organization steps forwards to organizational changes. Some of the approaches that might work for a private organization but using the same methods in public organizations may lead to conflicting consequences. In comparison to private organizations, public organizations have multi decision-making authorities, diverse stakeholders, and organizational vibrant is intensive and organizational design is based more on the bureaucratic side. Naturally, it is almost impossible to change bureaucracy thus challenges and obstacles for applying strategic management and leadership in public organizations won't be handled in near future.

When it comes to strategic changes in public organizations, it is very important to keep in mind that changes are more challenging than in private organizations. In public organizations, changes are carried out by top management, and employees do not involve with the planning phase and change process.

From beginning to the end public organizations should ensure that employees' participation is included in the change plan. The literature indicates that public organizations are behind private organizations in developing strategic management and leadership programs. They are behind, but they are making progress. With the contribution of more research focusing on strategic management in the public sector, developments of strategic leadership programs would improve and programs would be adapted faster than today.

Recently, practicing additional strategic leadership skills to be able to accomplish and grasp strategic management is required more than before for public managers. On the other hand as Nutt and Backoff $(1993 ; 330)$ 
emphasized because of media scrutiny and the requirement for open meetings, public leaders are limited in experimenting with ideas. They also point out that innovation without speculation about possibilities is difficult for public managers. Because of that situation, public managers are often forced to learn about objections and ways to overcome these objections first. Unfortunately, it is very true that worrying about wrongdoings limits leaders from developing creative and innovative ideas in public organizations.

In conclusion, this research revealed that public organizations are aware of the need for transition from classic leadership to strategic leadership. One of the challenges is that concepts of strategic leadership for the private sector do not apply to public organizations. Researchers and public organizations are still in search to find a way to make it applicable to public organizations. This paper has proposed that because of different organizational structures between the private and public organizations taken in the same approach in strategic leadership implications is inapplicable. Obstacles for adapting a strategic leadership approach in public organizations are also listed in this paper.

\section{REFERENCES}

ADAIR, J. (2005), Developing tomorrow's leaders, CBI Guide to Leadership, retrieved from, http://www.johnadair.co.uk/articles/Developingtomorrowsleaders.pdf

BRYSON, J., George, B. (2020). Strategic Management in Public Administration. Oxford Research Encyclopedia of Politics, 187-191. https://doi.org/10.1093/acrefore/9780190228637.013.1396

BOURGON, J., (2009), Understanding the public leadership environment: preparing people to serve people in the 21 st Century, CAPAM, Featured Report, p. 12-17

CAPAM Featured Report, (2009), Building public service leadership capacity, Commonwealth Association for Public Administration \& Management

CHEN, S.-S., (2006), Leadership Styles and Organization Structural Configurations, The Journal of Human Resource and Adult Learning, Volume 2, Number 2, November 2006.

GECÍKOVÁ, I., \& PAPCUNOVÁ, V. (2014). Using of Strategic Management Tools in Conditions of Local Self-government in Slovakia. Procedia - Social and Behavioral Sciences, 110, 969-978. https://doi.org/10.1016/j.sbspro.2013.12.943

GOULET, L. (1996) Perspectives in public management, strategic leadership for public service renewal, CCMD Publications on Public Management. Available at http://atlas101.ca/ic/wpcontent/uploads/2016/01/Perspectives_on_Public_Management_I.D.Clark_B.Dewar_L.Goulet_J.Davis_M.Keating_J.C\%C3\%B4t\%C3\%A9-OHara_1996.pdf

HASSAN , (2009), The new storm, building leadership through the currency of character, CAPAM, Featured Report, p. 8-11

HÖGLUND, L. M. H., \& SVÄRDSTEN, F. (2015). Strategic Management in Public Sector - Challenges in Theory and Practice. Nordic Academy of Management Conference, November.

HÖGLUND, L., HOLMGREN CAICEDO, M., MÅRTENSSON, M., \& SVÄRDSTEN, F. (2018). Strategic Management in the Public Sector: How Tools Enable and Constrain Strategy Making. International Public Management Journal, 21(5), 822-849. https://doi.org/10.1080/10967494.2018.1427161

JOYCE, P., (2004) Public sector strategic management: The changes required, Strategic Change, 13: 107-110

JURISCH, Ikas, Wolf, \& Krcmar. (2013). Key Differences of Private and Public Sector Business Process Change. E-Service Journal, 9 (1), 3-27. https://doi.org/10.2979/eservicej.9.1.3

KERLINOVÁ, A., \& TOMÁŠKOVÁ, E. (2014). Approach to Strategy at Public Administration Organizations in the Czech Republic. Procedia - Social and Behavioral Sciences, 156 (April), 88-92. https://doi.org/10.1016/j.sbspro.2014.11.125

KOOIMAN, J., VLIET, J.v (2000). Self-Governance As a Mode of Societal Governance. September 2000 Public Management 2(3):359-378. DOI: 10.1080/14719030000000022

LANE, J. E., \& WALLIS, J. (2009). Strategic management and public leadership. Public Management Review, 11(1), 101-120. https://doi.org/10.1080/14719030802494047

LEMAY, L., (2009), The practice of collective and strategic leadership in the public sector, The Public Sector Innovation Journal, Volume 14(1), article 2

MARIN, SC. (2016) Strategic Management in Public Administration International, Conference "Risk in Contemporary Economy” ISSN-L 2067-0532 ISSN online 2344-5386 XVIIth Edition, 2016, Galati, Romania, 187-191

MCBAIN, L., SMITH, J. (2010). Strategic Management in the Public Sector.E-Leader Singapore 2010, p. 111

MINTZBERG, H. (1989). Mintzberg on Management, The Free Press, New York.

MONTANARI, J. R., and BRACKER J. S., (1986), The strategic management process at the public planning unit level, Strategic Management Journal, Vol. 7, 251-265 
NAIDOO, G., (2010), Developing leadership and adopting an African leadership model for the improvement of public services in South Africa, CAPAM, Featured Report, p. 42-53

NUTT, P. C., and BACKOFF, W. R., (1993), Transforming public organizations with strategic management and strategic leadership, Journal of Management, Vol. 19, No. 2, pp. 299-347.

OECD (2001), Public Sector Leadership for the 21st Century, OECD Publishing, Paris, https://doi.org/10.1787/9789264195035-en.

OCHRANA, F., \& Potuček, M. (2010), Riziková budoucnost: Devět scénářů vývoje české společnosti a její neoweberovská kritika. Strategické řízení ve veřejné správě a přístupy k tvorbě politiky. 1. vyd. Praha: Matfyzpress, 2010, s. 97-102. ISBN 978-80-7378-130-9. Available at https://www.researchgate.net/profile/Maria_Svidroova/publication/304344125_Social_innovations_i $\mathrm{n}$ w ork organizing telework in Slovakia/links/584dd3a608aed95c250327f7/Socialinnovations-in-work-organizing-telework-in-Slovakia.pdf\#page $=167$

ÖNDER, M. (2018). An application of Strategic Management to the Public Sector: What accounts for Adoption of Reinventing Government Strategies Across the States of the United States. The proceedings of $6^{\text {th }}$ international strategic management, pp. 1043-1412

PFIFFNER, J. P. (2004). Traditional Public Administration versus The New Public Management: Accountability versus Efficiency. 1-10.

ROSENBERG, H. J., \& FERLIE, E. (2016). Applying Strategic Management Theories in Public Sector Organizations: Developing a typology. Public Management Review, 18 (1), 1-19. https://doi.org/10.1080/14719037.2014.957339

ROWE, W. (2001). Creating Wealth in Organizations: The Role of Strategic Leadership. The Academy of Management Executive (1993-2005), 15(1), 81-94. http://www.jstor.org/stable/4165712

SMINIA, H., NISTELROOIJ, A. V. (2006), Strategic management and organization development: planned change in a public sector organization, Journal of Change Management, Vol. 6, No. 1, pp. 99-113.

SHRIVASTAVA, P., NACHMAN, A.S., (1989), Strategic leadership patterns, Strategic Management Journal, Vol. 10, 51-66.

SCHALL, E., (1997), Public-Sector succession: a strategic approach to sustaining innovation, Public Administration Review, Vol. 57, No. 1, pp.4-10

STEURER, R. (2007). From government strategies to strategic public management: An exploratory outlook on the pursuit of cross-sectoral policy integration. European Environment, 17(3), 201-214. https://doi.org/10.1002/eet.452

TANER, A. (2018). Türk Kamu Yönetiminde Kamusal Hesap Verebililiğin Aracı Olarak Stratejik Planlama. Muhasebe Bilim Dünyası Dergisi, October 2017. https://doi.org/10.31460/mbdd.347518

TAYLOR, E. (2009), State of public service leadership capacity: Issues and options to assure adequacy of leaders in the public service, today and tomorrow, CAPAM, Featured Report, p. 18-26

UĞURLUOĞLU, Ö., ÇELIK, Y., and PISAPIA, J., (2010), Strategic leader actions related to the effectiveness of hospital managers in Turkey, American Journal of Business Research, Vol.3, No.1, pp. 33-52.

WANASIKA, I., (2009), In search of global leadership, Journal of International Business and Cultural Studies, Vol.1

WILLIAMS, W., \& LEWIS, D. (2008). Strategic management tools and public sector management: The challenge of context specificity. Public Management Review, 10(5), 653-671. https://doi.org/10.1080/14719030802264382 